\title{
The Politicization of European Union Trade Policy: Radical-Left Euroskeptic Opposition to the Transatlantic Trade and Investment Partnership
}

\author{
Filip Tereszkiewicz ${ }^{1+}$ \\ ${ }^{1}$ University of Opole, Poland
}

\begin{abstract}
This study aims to analyze the correlation between radical-left Euroskeptic (RLE) activity and European Union (EU) trade policy by focusing on the Transatlantic Trade and Investment Partnership (TTIP). At the beginning of TTIP negotiations, the agreement was not high on political agendas and was not a major concern within European society. Thus, its salience was low. This initial lack of interest stemmed from the fact that the TTIP, as an economic and technical issue, did not draw public attention. This study shows that RLEs profoundly affected public opinion on the TTIP by increasing its salience during the European parliamentary elections in 2014 in France and Germany. Second, RLEs involved social actors and non-governmental organizations in anti-TTIP campaigns and channeled European anxieties into the STOP TTIP European Citizens' Initiative. Third, RLEs used this proposed agreement between the EU and the United States to increase polarization within European society and ideological cleavages within the European Parliament. Finally, we can assume that an anti-TTIP campaign promoted by radical-right Euroskeptics would have had different drivers. Thus, my findings have implications for understanding the correlation between RLE activity and the politicization of EU trade policy, and they suggest some avenues for future research.
\end{abstract}

Keywords: European Union, Euroskepticism, global trade, politicization, radical left, trade policy, Transatlantic Trade and Investment Partnership

JEL Classifications: F13, F52, F53, F68, H77, K33

Received 8 January 2021, Revised 21 April 2021, Accepted 7 June 2021

\section{Introduction}

In 2006, the European Union (EU) launched the Global Europe Strategy, which signaled a significant change in its external trade policy by emphasizing the conclusion of deep and comprehensive free trade agreements (DCFTAs) (Petersmann, 2017). With this new generation of bilateral and multilateral agreements, the EU aims to pursue its deep trade agenda by going beyond the current provisions of the World Trade Organization and regulating non-tariff measures. Because tariff barriers between the EU and other developed countries are already relatively low, it follows that any agreement will limit any prohibitive barriers resulting from 
different domestic regulations (Griller et al., 2017). Thus, the deep and comprehensive character of new generation agreements will clearly increase economic globalization, which most of European society has perceived negatively since the 2008 debt crisis (Cyrus, 2015; European Commission, 2009; Morin et al., 2015; Puntscher Rieckmann, 2017). In recent years, EU trade policy has been seen as becoming politicized not only because of debates conducted in the EU and member states' legislatures but also because of massive protests held by civil society organizations and movements (Gheyle, 2016; Winslett, 2016). Additionally, the controversies that are generated by DCFTAs are being used by extreme politicians, especially radical-left Euroskeptic (RLE) parties, civil society organizations, and movements, to attack the EU. For radical-left politicians and activists, who historically have opposed neoliberalism, opposition to DCFTAs has understandably played an increasingly important role not only in their political campaigns but also in differentiating them from their mainstream and radical-right competitors (Charalambous et al., 2018; Keith, 2017; Meijers, 2017; Rone, 2018). All of these processes were especially visible in the debates on the Transatlantic Trade and Investment Partnership (TTIP). The TTIP triggered unprecedented public opposition in almost all EU member states and became the subject of a pan-European debate. Polls show that in some EU member states, public opinion about the treaty shifted from positive and neutral to negative over the course of several months. The campaign against the TTIP gained momentum in 2015 and 2016. If Donald Trump had not chosen to suspend negotiations, Europe would have voted down the treaty, either in the European Parliament (EP) or national legislatures. This outcome raises the question of whether RLE activity was correlated with the politicization of the TTIP. This problem is important to solve because scholars have given little consideration to the possibility that EU trade policy is the object of RLE actions that contribute to its politicization (Costa, 2019; Meijers, 2015, 2017). To address this question, I use a research design in which the politicization of the TTIP is the dependent variable and RLE activity related to the TTIP is the independent variable. I hypothesize that RLE activity and the politicization of the TTIP are positively correlated. I attempt to verify this hypothesis using the case study approach and content analysis tools.

Following Majone (2002), Hoeglinger (2015), De Wilde et al. (2016), and Grande and Hutter (2016), I operationalize the politicization of the TTIP (i.e., the dependent variable) as activity that increases the TTIP's salience and, thus, its audience and contestation; increases the polarization of public opinion and politicians' orientations toward the TTIP; involves social actors and nongovernmental organizations (NGOs) in the debate about the TTIP; and increases the ideological cleavage between political factions in the European Parliament (EP) (see Table 1). To measure the dependent variable, I include any public activity that focuses on the TTIP as part of the TTIP's politicization. I scrutinize the overall 2014 campaign in the EP, social media activity, public statements and speeches about the TTIP, debates in the EP, public demonstrations, and societal initiatives against the TTIP. I try to identify any indicators that these activities were 
motivated, inspired, and controlled by RLE politicians and activists.

Table 1. Components and Manifestations of Politicization

\begin{tabular}{ccccc}
\hline Salience & Polarization & Expansion of actors & $\begin{array}{c}\text { Increasing } \\
\text { the ideological cleavage }\end{array}$ \\
\hline $\begin{array}{c}\text { Micro } \\
\text { (beliefs) }\end{array}$ & $\begin{array}{c}\text { Importance of TTIP } \\
\text { relative to other issues }\end{array}$ & $\begin{array}{c}\text { Different beliefs } \\
\text { about TTIP }\end{array}$ & $\begin{array}{c}\text { Individuals with different } \\
\text { traits see TTIP as } \\
\text { important }\end{array}$ & $\begin{array}{c}\text { Politicians with different traits } \\
\text { see TTIP as important }\end{array}$ \\
\hline $\begin{array}{c}\text { Meso } \\
\text { (mobilization) }\end{array}$ & $\begin{array}{c}\text { Importance relative to } \\
\text { other targets of } \\
\text { mobilization }\end{array}$ & $\begin{array}{c}\text { Mobilized groups } \\
\text { stand for different } \\
\text { positions }\end{array}$ & $\begin{array}{c}\text { Many different types of } \\
\text { groups mobilize }\end{array}$ & $\begin{array}{c}\text { Different types of political } \\
\text { parties mobilize }\end{array}$ \\
\hline $\begin{array}{c}\text { Macro } \\
\text { (public debates) }\end{array}$ & $\begin{array}{c}\text { Often mentioned in media } \\
\text { (relative to other issues) }\end{array}$ & $\begin{array}{c}\text { Polarization of } \\
\text { statements/claims }\end{array}$ & $\begin{array}{c}\text { Expansion of contributors } \\
\text { to the debate }\end{array}$ & $\begin{array}{c}\text { Political parties (and politicians) } \\
\text { from different ends of the } \\
\text { ideological spectrum contribute } \\
\text { to the debate in the EP. }\end{array}$ \\
\hline
\end{tabular}

Based on Zürn, 2016, 169.

To measure the independent variable, that is, RLE activity on the TTIP, I focus on parties, movements, and social organizations that I identify as RLE groups. Specifically, I define a party, movement, or social organization as being an RLE group if it is based on economic and territorial nationalism; favors a workers' democracy; supports a mixed market economy (and an active role of the state in controlling the economy); opposes trade liberalization, marketization, and privatization; and is pessimistic about the EU's current direction.

To determine whether RLE activity is correlated with the politicization of the TTIP, I ask the following four sub-questions. Did RLEs increase the TTIP's salience and, thus, its audience and contestation? Did RLEs increase the polarization of public opinion and politicians' orientations regarding the TTIP? Did RLEs involve social actors and NGOs in the debate about the TTIP? Did RLEs use the TTIP to increase the ideological cleavage between political factions in the EP? If I can answer all of these questions in the affirmative, then I can conclude that RLE activity is correlated with the politicization of the TTIP, verifying my hypothesis. If I cannot answer any of them in the affirmative, then I can conclude that the two issues are not correlated, implying that my working hypothesis is not verified. Similarly, if I can answer only some of them in the affirmative, then there is insufficient evidence of a politicization strategy by RLEs, contradicting my working hypothesis.

This study contributes to the existing literature in three ways. First, it produces new knowledge on Euroskepticism. Political parties and movements with distinct anti-European platforms have gained considerable electoral representation in recent years (Halikiopoulou, 2018; Rooduijn et al., 2017). Nevertheless, the current understanding of the impact of Euroskepticism on EU trade policy is limited (De Vries, 2018; Leruth et al., 2018; Szczerbiak \& Taggart, 2018). Thus, this study fills a gap in the research on RLE activity in the area of EU trade policy. Additionally, it increases the body of knowledge about RLEs. Unlike radical-right Euroskeptics (RREs), the 
radical left has received less attention from scholars. Nonetheless, the recent political advances of radical left groups in Europe, such as Greece's Coalition of the Radical Left, Spain's Podemos, Germany's Left Party, and La France Insoumise, have demonstrated the importance of understanding the impacts of these parties (Charalambous, 2011; Chiocchetti, 2014; Holmes \& Lightfoot, 2016; Keith, 2018; Rooduijn et al., 2017; Van Elsas et al., 2016). Second, this study provides empirical knowledge on the politicization of the EU using EU trade policy as an example. It is important to understand the degree to which trade policy issues are contested, who is involved in the contestation, and how this contentiousness translates into decision-making processes. This study also provides knowledge of the politicization patterns that RLEs utilize in the context of EU trade policy. Finally, the third contribution of this study is related specifically to EU trade policy. In recent years, research on EU trade policy has increased, and numerous methodological frameworks have been constructed to examine it. However, these studies mostly focus on the potential influence of the EU's institutions and member states on EU trade policy. Some studies investigate the right-wing and left-wing populist influences on EU trade policy. However, few studies look at the effect of Euroskepticism on EU trade policy, especially within the framework of politicization. Thus, this study increases knowledge about Euroskeptic activity related to EU trade policy and introduces an analytical framework for future investigations.

This paper proceeds as follows. Section 2 outlines key concepts (i.e., the definition of RLEs and the phenomenon of politicization within the EU), describes the data, and builds an analytical framework for the research. Section 3 describes the case study. Section 4 concludes and addresses the correlation between RLEs and the politicization of EU trade policy more broadly.

\section{Key Concepts and Data}

\section{A. Defining radical-left euroskepticism}

As studies increasingly investigate political parties' relations with European integration, the methodological question of how to study radical-left opposition to EU trade policy arises (Leconte, 2015; Pirro \& Taggart, 2018). This study utilizes Euroskepticism as a conceptual instrument for researching the politicization of this issue, focusing on the TTIP as an example. In analyses of Euroskepticism, many approaches have been used to distinguish between its different types, including "hard" and "soft" Euroskepticism (Taggart \& Szczerbiak, 2004); "Eurorejects," "Euroskeptics," and "Europragmatists" (Kopecký \& Mudde, 2002); "Rejectionist Euroskepticism," "Conditional Euroskepticism," and "Compromising Euroskepticism" (Vasilopoulou, 2011); and "Far Left Euroskepticism" and "Far Right Euroskepticism" (Meijers, 2017). This study uses the radical-left and radical-right dichotomy and focuses on radical-left Euroskepticism as the source of the TTIP's politicization. 
March (2008) describes radical-left parties, movements, and organizations as those that define themselves as being to "the left of social democracy, which they see as insufficiently left-wing" (p. 1). In his view, the radical left accepts democracy but favors workers' democracy and the direct participation of labor in managing the economy. These parties are anti-capitalist and oppose globalization, which involves trade liberalization, marketization, and privatization, although they "no longer support a planned economy but a mixed market economy with private enterprise confined to services and small- and medium-sized enterprises" (March, 2008, p. 3). This concept of the radical left allows me to define RLEs as parties, organizations, and movements that are oriented in opposition to capitalism, global free trade, and the EU. These parties, organizations, and movements are driven by a protest strategy and are incentivized to oppose the EU to differentiate themselves from their mainstream-left and radical-right rivals. Here, the ideological ground is that the EU project stands in opposition to the radical left's core values because the EU favors neoliberal policies and the free market (Hooghe et al., 2002). RLEs believe that the EU contains an institutional asymmetry in favor of market making instead of market regulation (Scharpf, 1996). However, as Halikiopoulou et al. (2012) note, RLEs have become increasingly nationalistic, justifying their opposition to the EU on the basis of national sovereignty. This view brings them closer to their radical-right counterparts. However, unlike the radical right, radical-left Euroskeptic platforms are based on economic and territorial nationalism and see the EU as an imperialist entity that pursues the interests of the neoliberal ruling class (Halikiopoulou et al., 2012). According to RLEs, egalitarian social policies cannot be realized within the current post-Lisbon institutional framework (Meijers, 2017). These parties, civil society organizations, and movements wish to reform the EU rather than abandon it, and only a few RLEs (e.g., the Communist Party of Bohemia and Moravia, the Communist Party of Greece, the Portuguese Communist Party, and the Red-Green Alliance from Denmark) call for their countries to withdraw from the EU. Thus, it is simplistic to describe radical-left parties, movements, and organizations as Euroskeptic, as some advocate withdrawing from the EU, whereas others want to reform it (Conti \& Memoli, 2012; Dunphy, 2004). Nevertheless, as Keith (2018) notes, they are all commonly opposed to "the EU in its current form" (p. 90). Regardless of the differences among RLE parties, public distrust of the EU will arguably increase their mobilization potential, especially because the center-left's pragmatic adaptation to the free-market economy has hitherto allowed RLEs to adopt opposition to the EU as an identity marker vis-a-vis social democracy (March \& Rommerskirchen, 2015).

It is important to emphasize that political parties, organizations, and movements in EU member states often view the EU as neoliberal in character with a positive view of global free trade (Hooghe et al., 2002; Hooghe and Marks, 2009). According to RLEs, the EU's trade policy is an example of this positive attitude towards globalization. Additionally, the EU has expanded in competency from liberalizing markets and opening up domestic economies to becoming more 
directly involved in the functioning of its member states' legal systems and social programs. Thus, Euroskepticism has also become a radical-left phenomenon in recent years (Hooghe et al., 2002). Far-left Euroskeptics oppose the neoliberal character of integration and encourage voters to oppose the EU using economic insecurity arguments (Braun et al., 2019; Hooghe et al., 2002; De Vries \& Edwards, 2009). The latter action is easy to link with EU trade policy, which promotes the liberalization of global trade and weakens the European welfare state model.

Studies that focus on radical-left group cohesion present the radical left as no more divided than other party families are (Hix \& Lord, 1997; Keith, 2018; Volkens, 2004). However, Charalambous (2011) states that the radical left as a whole contains no systematic congruence. Nevertheless, a European Left Party has existed since 2004, and most parties in the United European Left/Nordic Green Left (GUE/NGL) grouping in the EP are either members or observers. Most importantly, all of these parties agree on common directions in a number of policy domains, including regional policy, social and economic cohesion, and environmental protection (Dunphy, 2004; Hough \& Handl, 2004). Additionally, these parties are often directly linked to civil organizations, such as labor unions, consumer organizations, and alter-globalization movements, to a certain extent. This variety of forms of RLEs indicates that they are constantly debating the prospects of European integration (Charalambous, 2011). Dunphy (2004) warns that they "are divided in their strategic assessment of whether common goals are best realised through deepening EU integration or in contesting and perhaps rejecting the current model of European construction altogether" (p. 167). Thus, radical-left parties, civil society organizations, and movements are not the associative issue owners of hard Euroskepticism, as they do not oppose integration in principle but merely oppose the economic goals that they believe the EU embodies (Helbling et al., 2010). It is reasonable to assume, however, that they can influence other party positions in the issue areas for which they are the associative owners. Radical-left parties are generally seen as the associative issue owners for state control of the economy (Halikiopoulou, 2014), and they can therefore influence other positions related to EU trade policy. Thus, systematic congruence among the parties regarding EU trade policy issues can be expected, and mainstream parties will move towards this position to avoid losing voters who care about global trade liberalization (Williams \& Ishiyama, 2018).

\section{B. Politicization within the EU}

For many years, scholars have studied the politicization process in the European context. Politicization has many definitions, but different scholars focus on different aspects of the process. For example, Hoeglinger (2015) states that politicization can be understood as a process by which a particular political issue enters the field of mass politics, namely, a process by which the audience is widened and public contestation increases. Rixen and Zangl (2013) agree with 
him, adding that this process means that "issues that did not catch the eye of the general public previously are debated in the public sphere" (p. 365). De Wilde (2011) tries to put forth a more accurate definition, stating that politicization always consists of three interrelated components: the polarization of opinions, an intensifying debate, and public resonance. Grande and Hutter (2016) also use three interrelated dimensions to characterize politicization: polarization, issue salience, and actor expansion. Hoeglinger (2015) similarly states that politicization is a threefold process that comprises the polarization of politicians' orientations, the intensification of public debate, and the connection of the issue to core political concerns, thereby creating wider resonance and mobilizing the audience.

In the context of EU trade policy, the question of whether politicization within the EU framework has the same features as politicization within nation-states also arises. Schmitter (1969), who researches politicization in integration processes, emphasizes classical aspects of the process. For him, it is a "rise in the controversiality of the regional decision-making process" because "national actors find themselves gradually embroiled in ever more salient or controversial areas of policy-making" (Schmitter, 1969, pp. 161-166). As such, he concentrates on growth in the controversial aspects of an issue. Schmidtke (2013), who concentrates on politicization within international institutions, notes that it is "the communicative processes that lead to an increasing intensity and controversy of debates on international institutions in the broader public, encompassing not only political executives but also party politicians, NGOs, and other interest groups" (p. 3). Further, he states that not only governments and politicians but also social actors and NGOs are relevant. De Wilde (2011) establishes a definition of politicization within the EU framework, saying that there is "an increase in polarisation of opinions, interests or values and the extent to which they are publicly advanced towards the process of policy formulation" (p. 566). According to him, politicization involves actors publicly presenting themselves as representatives and contesting other representatives. De Wilde (2011) notes also that the concept of politicization is used to describe the involvement of societal actors, such as political parties, mass media, interest groups, social movements, and citizens, in EU politics through public opinion. Christiansen (1997) also focuses on politicization within EU institutions and notes that the term is used to describe a change in decision-making processes, representing a shift away from the EU's more typical technocratic decision-making. He also says that the decision- making process is increasingly being subject to pressure from different advocacy coalitions, simultaneously increasing both the controversy surrounding the issue at hand and the prominence of more political decisionmaking bodies within EU institutions, such the EP. Hooghe and Marks (2009) argue that politicization is the key mechanism behind the change in the EU's political climate from a permissive consensus to a constraining dissensus. Additionally, Majone (2002) stresses that politicization implies that the importance of party politics and ideological cleavages is growing. Thus, EU trade policy is a suitable area of politicization for RLEs because it fits not only in 
the ideological cleavage between the right and the left but also in that between Europhiles and Euroskeptics, which include the populist right, national conservatives, and, of course, the radical left (Hooghe \& Marks, 2009, p. 21). Although mainstream parties try to depoliticize European integration, as they internally disagree on this issue, Hooghe and Marks (2009) argue that they ultimately fail to do so.

The politicization of EU issues can be categorized as the politicization of institutions, decisionmaking processes, and issues. The first category refers to EU institutions, particularly the EP. The second category includes the procedures, rules, and practices that comprise the day-to-day functioning of EU institutions. Finally, the politicization of issues refers to increases in the salience and diversity of opinions on specific topics. If an issue is becoming more contested and public demand for public policy is increasing, then that issue is then considered to be politicized (De Wilde, 2011). Grande and Hutter (2016) also emphasize the salience of a politicized issue, which refers to the visibility of a given issue in public debates. Only topics that are frequently raised by political actors in public can be considered politicized. This idea mirrors Green-Pedersen's (2012) and Guinaudeau and Persico's (2013) suggestions to view politicization primarily through the lens of salience. Grande and Hutter (2016) stress that the expansion of the actors involved in public debates is an important aspect of politicization. They argue that the number of people involved in a conflict determines the outcome. If only a few elite actors publicly advance their positions on an issue, then that issue is hardly politicized. Clearly, if no one discusses an issue, it is not politicized. According to Hoeglinger (2015), this idea is "far from trivial since the carrying capacity of the public sphere is highly limited and many more issues compete for attention than actually make it into the news, let alone them becoming established as a regular topic of debate" (p. 14). Thus, public resonance and the engagement and mobilization of citizens around an issue are also necessary for politicization.

The politicization of issues within the EU is important because parties, civil society organizations, and movements can use controversial topics to increase politicization within Europe as a whole. An issue can only become politicized when at least two different opinions on the issue are put forth (Tilly \& Tarrow, 2007). These opinions must be articulated by certain representatives, such as politicians, civil society organizations, and movement activists, who view themselves or their constituencies as having an interest in the topic. The more an issue is discussed, the more politicized it becomes (De Wilde, 2011).

Table 1 shows that including micro-, meso-, and macro-level politicization in the concept of politicization allows for more nuanced descriptions and typologies of politicization as opposed to taking an all-or-nothing view. In some cases, politicization may take place only in the media with no associated political mobilization and truncated individual attitudes. Full politicization may arise if significant changes occur along all four dimensions (salience, polarization, expansion of actors, and increasing the ideological cleavage). It may be worth investigating which types 
of politicization are complementary to develop an understanding of the ideal type (Zürn, 2016).

\section{Data}

I derive the necessary data for measuring the politicization of the TTIP from primary and secondary sources. Examining primary sources is crucial for gathering evidence that some dimensions of politicization occur and demonstrating that RLE activity is correlated with the politicization of the TTIP. To conduct content analysis, I utilize traditional media about the TTIP, such as public speeches and EP debates, social media outlets (e.g., Twitter and Facebook), and websites related to radical-left Euroskepticism and the TTIP. I try to identify typical RLE arguments and other indications that RLEs framed the discourse about the TTIP. I also utilize other primary sources, such as data about societal attitudes, attendance at demonstrations, and the results of votes on TTIP resolutions in the EP. My secondary sources include literature, expert reports, and working papers on the TTIP's politicization and the anti-TTIP movement. Recent studies on the TTIP (Bauer, 2016; Buonanno, 2017; De Bièvre, 2018; Eliasson \& Huet Garcia-Duran, 2018; Garcia-Duran \& Eliasson, 2017; Gheyle, 2020; Organ, 2017; Young, 2016, 2017) do not deeply scrutinize the role of RLEs, which makes this study novel. I also carefully examined secondary literature in the initial stages of the analysis to finalize the development of a theoretical framework for examining the politicization process to be tested in the case study.

\section{Case Study of Four Steps in the TTIP's Politicization by RLEs}

\section{A. Increasing the TTIP's salience}

It is generally acknowledged that the TTIP has led to unprecedented debate within Europe (De Ville \& Siles-Brügge, 2017), mainly because the proposed agreement between the EU and the United States (US) was uniquely ambitious in its efforts to address non-tariff measures that affect international trade. These measures have more direct implications for citizens than tariffs have. The impacts of tariff changes on consumers tend to be both relatively small and difficult to notice. As a result, European citizens are not normally expected to have sufficient motivation to engage with EU trade policy (Young, 2017). Public attention on the TTIP increased noticeably and sharply in Europe in the spring of 2014 ahead of the May EP election (Buonanno et al., 2015; Smyrnaios, 2014). Since then, public opposition to the treaty has continued to rise (YouGov Deutschland, 2015). At first, the TTIP was not salient in EU member states among politicians or citizens, although the lack of transparency during the negotiation process and the lobbying of international companies in the EU raised some concerns (Puntscher Rieckmann, 2017). Opposition to the TTIP varied sharply among EU member states. At first, it was particularly 
high in France and Germany, but some concerns were also raised in Austria and Luxembourg (Standard Eurobarometer 82, 2014). In all of these states, some indicators suggest that RLE politicians and activists inspired these anxieties.

In France, the TTIP issue was used by the Left Front and Europe Ecology - The Greens parties in their election campaigns in 2014. These parties put the spotlight on the sanitary, phytosanitary, and environmental issues of the agreement, but they were mainly concerned about low American food standards (Mélenchon, 2014; Traité transatlantique, 2014). This political action of French RLEs forced the remaining political competitors to voice their opinions, thereby increasing the salience of this issue (Fabry, 2015; Xavier-Bender, 2015). In France, the TTIP's politicization was driven by the municipal and regional councils' demand for a transparent debate about the treaty and the publication of all documents about the negotiation process. Because the European Commission (EC) did not react to this requirement, the debate grew more heated, and French regions, departments, and municipalities with large numbers of RLE politicians on their councils declared an area outside the TTIP (Fabry, 2015; Stop TAFTA, n.d.; TTIP Free Zones Europe, n.d.).

The TTIP achieved salience in Germany for different reasons than it did in France, but RLEs were involved in both cases (Bauer, 2016; Mayer, 2016). The investor-state dispute settlement (ISDS) issue emerged in Germany because of Germany's negative experience with Vattenfall, which sued Germany in 2012 in arbitration court for the nuclear phase-out decision (BernasconiOsterwalder \& Tamara Hoffmann, 2012). For that reason, the ISDS clause catalyzed the TTIP's importance (Chan \& Crawford, 2017)1). As in France, some indicators in Germany suggest that RLEs created the TTIP's saliency. The most visible effort was undertaken by Campact, an NGO associated with The Left, a German RLE party (Bauer, 2015a, 2016). Over several months, Campact mobilized thousands of people to take part in anti-TTIP protests (Behrens, 2015; Campact, 2015), demonstrating that the TTIP's importance had increased relative to that of other mobilization targets. After this political action, support for the TTIP dropped from 55 to 17 percent (Bluth, 2016). Campact's activists effectively used selective trigger words and provocative framing in public speeches and debates to win public support against the TTIP, as they asserted that the TTIP's provisions serve big businesses instead of ordinary people and undermine Europe's democratic standards (Burchard, 2016; Campact, n.d.). This argument fit with RLEs' image of the EU as an imperialist entity that pursues the interests of the neoliberal ruling class (Halikiopoulou et al., 2012).

In October 2015, demonstrations organized by radical-left activists included more than 150,000 participants, and discontent boiled over into other members of the EU (Steiner, 2016), motivating the STOP TTIP European Citizens' Initiative. Between October 7, 2014, and October 6, 2015, $3,300,000$ signatures were collected, and the legal minimum amount of support was achieved

1) On April 30, 2019, the European Court of Justice gave the opinion (1/17) that the mechanism for the settlement of investor-state disputes was compatible with the EU Treaties and the EU Charter of Fundamental Rights. 
in $23 \mathrm{EU}$ member states. This outcome highlights the importance of the TTIP in European society and the opposition to this treaty beyond German and French borders. However, the EC rejected this petition in September 2014, further increasing the sentiment that the partnership was harmful to ordinary people (STOP TTIP, 2015). Additionally, Greenpeace revealed documents about TTIP negotiations in May 2016 that deepened public resentment even more (Greenpeace, 2016b).

ISDS was quickly deemed a useful target that could be drastically simplified for the general public to garner attention and raise awareness of the TTIP. Although Europe has a wealth of experience with ISDS through bilateral investment agreements, the issue was unknown to the general public prior to 2014. Arguments in favor of corporations suing governments in secret courts over policies that they do not support (and that threaten the European welfare state model) were continuously repeated in protests, panel discussions, YouTube videos, tweets, position papers, reports, and press releases (e.g., Akcja Demokracja, 2015; Campagna STOP TTIP Italia, 2015a; Greenpeace, 2016a; Mélenchon, 2015a, Razem, 2016; Scholz, 2015a). Thus, the salience of ISDS as an issue appears to have been higher in countries that were on the receiving end of investors' claims, making people in these countries more receptive to the framing of ISDS as a threat to regulatory autonomy (Meunier \& Morin, 2017; Young, 2017).

Eliasson and Huet Garcia-Duran (2018) assert that specific issues, such as food safety and ISDS, were chosen by anti-TTIP activists because they helped to increase the TTIP's general salience, which, in turn, enabled lobbying, protests, and campaigns on technical details and other specifics. Initially, the American process of chlorinated microbial poultry washing was a natural focus for activists because the issue connected an appealing food with chemicals. RLE politicians and activists presented American standards as "weak" and "less safe" in social media posts, online videos, protests, and public statements (Mélenchon, 2016; Smyrnaios, n.d.; STOP-TTIP-Milano, n.d.; TNS Emnid, 2015; Xavier-Bender, 2015). In general, the European public increasingly agreed with them. This issue, which citizens understood and could readily grasp, enabled RLE politicians and activists to draw the European public's attention to the TTIP using the classic strategy of issue linkage (i.e., the aforementioned ISDS mechanism in this case). Just as Europeans think that Americans are more tolerant of questionable food safety practices, Europeans generally perceive Americans as more litigious, making them receptive to the argument that the ISDS chapter of the TTIP would expose EU member states to lawsuits from American companies. RLE politicians and activists argued that ISDS would allow American corporations to sue EU member states that adopted legislation to protect consumers and workers (e.g., Campagna STOP TTIP Italia, 2015b, 2016c; Mélenchon, 2015c; Razem, 2016; Scholz, 2015a). The reasoning in EU member states was that corporations would argue that the new regulations reduced company profits, thereby reducing the value of their original investments. Thus, although the concrete topics addressed by critics of the TTIP differed across countries, the issues of food safety and ISDS were raised in debates in almost all EU member 
countries (Bauer, 2016).

Thus, according to Garcia-Duran and Eliasson (2017), the controversies related to ISDS and food safety (e.g., sanitary and phytosanitary processes, hormone-treated beef, and genetically modified organisms (GMOs)) were strategically chosen by anti-TTIP activists to maximize the perceived threat to consumer interests and safety posed by the TTIP, helping them to convince the European public that the TTIP would harm product safety and public health. They were therefore able to increase the salience of this topic (Gheyle, 2020). The TTIP was presented in social and traditional media as a trade-off between neoliberalism (or wild-west capitalism) and popular sovereignty (Mélenchon, 2015b; Scholz, 2015b; Smyrnaios, n.d., 2014; Xavier-Bender, 2015), in accordance with radical-left critiques of the EU. Thus, RLE activities and the increased salience of the TTIP are observably correlated. Through various activities, such as highlighting food safety and ISDS treaties (and therefore framing the discourse about the TTIP), organizing demonstrations, and mobilizing the STOP TTIP European Citizens' Initiative, activists increased the TTIP's salience on the micro, meso, and macro levels, thereby increasing its audience and contestation.

\section{B. Increasing the polarization of public opinion and politicians' orientations regarding the TTIP}

Political parties and movements with distinct anti-European platforms have gained considerable electoral representation, and the growing number of negative opinions about the EU has led to the increased polarization of formerly non-controversial issues (Hoeglinger, 2015). The TTIP is a good example of a formerly consensual issue that became polarized. At the beginning of the TTIP negotiations in 2014, 59 percent of Europeans and 26 of the EU's 28 member states said they were in favor of the new partnership with the US (Standard Eurobarometer $82,2014)$. The TTIP was not controversial for the majority of citizens and politicians in the EU. Beginning with the EP election campaign in 2014, RLE politicians and activists aimed not only to increase the TTIP's salience but also to change the political climate around the TTIP and increase polarization within European society. Thus, they tried to shift the focus of the European debate away from the TTIP's economic and regulatory potential, which was emphasized by the EC. The benefits to the EU's economy were questioned, and RLE groups underscored the potential costs associated with the TTIP to achieve a framing effect (Mélenchon, 2015a; Scholz, 2015c). These arguments were captured by European consumers, welfare organizations, and environmental organizations, demonstrating the success of the RLE strategy (Campagna STOP TTIP Italia, 2016b; Foodwatch, 2015b; Greenpeace, 2016a; Ségol, 2015). Anti-TTIP activists also used the advantages gained by the business groups favoring free trade, such as access to the EC, to generate negative emotional responses to the treaty. Campaigners tapped into typical arguments for Euroskeptic groups, that is, discontent over the technocratic 
repression associated with European integration and the elite-driven process of strategically using the imperatives of economic integration to achieve greater political integration (Campact, 2015; Campagna STOP TTIP, 2015a). Indicators therefore suggest that RLEs used a polarization strategy to frame the discourse around the TTIP and, consequently, to further separate EU bureaucrats and the mainstream parties that serve international corporations' interests from the radical-left parties and movements that represent ordinary people within Europe. Different beliefs about the TTIP and polarized statements were present in Europe, but the dominant mobilization stemmed from only one group: anti-TTIP activists. It follows that full polarization regarding the TTIP increased on the micro and macro levels, with less mobilization of pro-TTIP activist groups on the meso level.

Bauer (2016) finds evidence that RLEs followed an international strategy. According to him, the widespread aversion to the TTIP in some EU member states resulted from an orchestrated, top-down campaign initiative launched by a small number of long-established, well-connected, and highly influential members of radical green and left political parties and the associated NGO campaign managers with Euroskeptic orientations. He asserts that protest groups' activities were coordinated by several former and current green and left-wing Euroskeptic politicians, such as Klaus Buchner, Harald Ebner, Klaus Ernst, Sven Giegold, Uwe Hiksch, Christa Luft, Fabio de Masi, Jean-Luc Mélenchon, and Helmut Scholz (Bauer, 2016). Using generous public funding and undisclosed private donations, they created a negative campaign and maintained influential networks of activists. The anti-TTIP campaign was effective because the issue's salience increased and opposition to the TTIP had become very active. For example, in Germany, well over 75 percent of the TTIP events were organized by opponents (meso level), and 42 of the 50 most requested and cited experts in 2015 opposed the TTIP (macro level) (Bauer, 2016). RLE activity against the TTIP was also effective because its message was targeted to address the common-sense protectionist demands of generally ill-informed citizens, journalists, and politicians. The negative messaging was based on innuendo and unlikely myths to effectively evoke citizens' emotions (Bauer, 2015b, 2016). The intensity of public opposition to the TTIP coincided with the vigor of the anti-TTIP campaign, which was waged extensively on Twitter ${ }^{2}$ ) and Facebook ${ }^{3}$ ) (micro level) (Smyrnaios, n.d., 2014) and was supported by public meetings and demonstrations (meso level) (Campact, 2015; Campagna STOP TTIP Italia, 2016a; Fabry, 2015). Thus, in contrast to traditional mass media coverage, social media coverage of the TTIP was overwhelmingly negative (Smyrnaios, n.d.; Young, 2017), indicating polarization on the macro level. These campaigns influenced European public opinion on the TTIP, which subsequently became more negative (Buonanno, 2017). Anti-TTIP propaganda and demonstrations effectively polarized public opinion because they underscored the dichotomy between common people and

2) The size of the campaign can be measured by tweets with the hashtags \#anti-TTIP and \#StopTTIP.

3) The size of the campaign can be measured by Facebook accounts connected to FLEs and anti-TTIP movements. 
EU bureaucrats who served international corporations. However, an interesting process took place on the micro level, as general support for EU trade policy was not correlated with specific support for the TTIP. Many EU citizens simultaneously supported free trade and opposed the TTIP (Standard Eurobarometer 84, 2015). Thus, the anti-TTIP campaign that radical-left activists conducted was clearly linked to public concerns about the TTIP in particular (Young, 2017). Two drivers of the anti-TTIP campaign (i.e., food-safety and ISDS) proved quite effective, and they shifted many people's opinions on the TTIP from indifference or diffuse support to outright opposition, thereby increasing polarization within European society at all levels of politicization (see Table 1) (De Bièvre, 2018). The food safety argument may be directly linked with the economic and territorial nationalism that is typical of RLEs (Mélenchon, 2016; STOP-TTIP-Milano, n.d.). Additionally, the resentment towards ISDS is rooted in opposition to trade liberalization, marketization, and privatization, which is also characteristic of RLEs. This aspect of the anti-TTIP framing was useful in increasing polarization on the macro level (see Table 1). It pressured certain key actors to join the anti-TTIP camp, especially social democratic politicians in key EU member states and political groups in the EP (Siles-Brügge, 2017). The anti-TTIP campaign inspired and conducted by RLEs (e.g., the Left Front, the Socialist Left Party, the Left, Campact, the Association for the Taxation of Financial Transactions for the Aid of Citizens (ATTAC), Progressi, Instytut Spraw Obywatelskich, and the Rosa Luxemburg Foundation) therefore showed that even mainstream parties can move away from a permissive consensus on EU issues if the framing is executed precisely (Bauer, 2016; Hoeglinger, 2015).

Thus, RLE activity is clearly correlated with the increasing polarization of public opinion and politicians' orientations regarding the TTIP. RLE politicians and activists used public speeches, debates, social media activity, protests, and demonstrations to negatively frame the public discourse about the TTIP. Their campaign tried to establish well-worn dichotomies, such as cosmopolitanism versus nationalism, EU bureaucrats and elites versus ordinary Europeans, trade liberalization and privatization versus anti-globalism and anti-capitalism, and optimism versus pessimism about the EU's current direction. Polarization on all levels (see Table 1) and the rising salience of the TTIP also helped RLEs increase polarization among European politicians, especially along ideological lines between the right and left. Thus, polarization within European society increased further, and public opinion in dozens of EU member states was largely divided into two camps (Bauer, 2016; Buonanno, 2017; De Bièvre, 2018).

\section{Involving TTIP social actors and NGOs in the debate}

As mentioned previously, the campaign against the TTIP was highly professionalized, top-down, and trans-European (Gheyle, 2020). However, some attempted to present opposition to the TTIP as grassroots (Eliasson \& Huet Garcia-Duran, 2018). Thus, RLE politicians and 
activists tried to involve social actors and NGOs that were usually not interested in EU trade policies in the debates (e.g., Campagna STOP TTIP Italia, 2016b; Die Linke, 2014; Foodwatch, 2015a; Mélenchon, 2015a). This strategy was important because, as Grande and Hutter (2016) explain, expanding the actors involved in public debate was crucial to politicizing the treaty. Thus, public resonance, engagement, and the mobilization of citizens around anti-TTIP activity were all needed (Hoeglinger, 2015).

The EC made grassroots involvement easier because of the TTIP's comprehensiveness, which, according to Young (2017), motivated an unusually broad and diverse array of groups to engage in opposition to the agreement. Thus, in addition to established anti-globalization groups, such as ATTAC, Corporate Europe Observatory, Friends of the Earth Europe, Public Citizen, and Campact, many consumer, public health, and environmental groups that had not previously engaged with trade policy entered the debate over the TTIP. Not all members of the latter group of organizations represent typical views of RLEs, but they became allies of RLEs in the anti-TTIP campaign. Thus, the mobilization of many different types of groups is visible on the meso level because these groups captured anti-TTIP slogans and arguments, especially arguments that presented the new treaty as a risk to food security.

The involvement of social actors and NGOs in the discussion of the TTIP was clear in many European countries. Members and supporters of these entities engaged in anti-TTIP activity not only on social media but also in public protests and demonstrations in a dozen EU member states, such as Germany, France, Italy, and Poland, at the micro and meso levels (Campact, n.d.; Comitato STOP TTIP Torino, 2016; Mélenchon, 2015a; Razem, 2016). Although a variety of these types of organizations were active in different EU member states, three types of actors were especially prominent in almost all EU members: labor unions, farmers' and local producers' associations, and environmental groups (Gheyle, 2020). The profiles of these organizations indicate that they may have had direct and indirect links with RLEs (e.g., Campagna STOP TTIP Italia, 2016b; Foodwatch, 2015b; Greenpeace, 2016a; Ségol, 2015). Direct links between labor unions and communist and radical left parties are clear; such groups are often associated with each other (Bauer, 2016; Fabry, 2015). In contrast, producers' associations and environmental groups are often officially independent, although they may be personally or financially linked with radical-left and radical-green parties (e.g., the Left or the Left Front) and NGOs (e.g., ATTAC, Campact, and the Rosa Luxemburg Foundation) (Bauer, 2016). Not all of these groups are directly controlled by RLEs, but many of them were inspired by RLEs. Eliasson and Huet Garcia-Duran (2018) lend credence to this observation by emphasizing the centralized natures of the anti-TTIP campaigns. They note that some anti-TTIP activity was coordinated at the European level under an umbrella organization called Stop TTIP!, which was organized by radical-left activists who supported important RLE values, such as workers' democracy, anti-globalism, and anti-capitalism (e.g., ATTAC, Campact, and Instytut 
Spraw Obywatelskich) (ATTAC, n.d.; Bauer, 2016; Instytut Spraw Obywatelskich, n.d.; Über Campact, n.d.). The ideologically-neutral name of this organization indicates that RLE activists attempted to obscure their radical-left image and the involvement of social and non-governmental entities with ideological roots in the debate about the TTIP.

As a result of this centralized initiative, the anti-TTIP groups exhibited a remarkable degree of consistency regarding the aspects of the treaty that concerned them. These groups, regardless of their country of origin, were mainly motivated by the ISDS and threats to food security (Buonanno, 2017; Fabry, 2015; Young, 2017). Hence, in trying to understand opponents' inroads and supporters' failure to control the debate about the treaty, it is important to highlight this "astroturf" nature of the anti-TTIP campaign. The unprecedented engagement of civil society groups was inspired, motivated, and activated by RLE politicians and activists, who not only increased the salience of the issue and framed the discourse by creating the aforementioned two drivers of the anti-TTIP campaign but also helped to organize particular actions and events that were officially politically independent. Inspiration from RLEs was also found on social media, where radical-left arguments, such as the protection of labor rights, food security, and opposition to special rights for global corporations, became popular (Campact, 2016; Smyrnaios, n.d., 2014; Troisi, 2016)4). These observations demonstrate the correlation between RLE activity and the involvement of social actors and NGOs in the TTIP debate. Additionally, this strategy provided extra benefits for radical-left politicians on the macro level. Siles-Brügge (2017) argues that this superficial civil society organization campaign against the TTIP resonated with key member states, such as France and Germany, and with many social democratic and radical-right members of the EP (MEPs), thereby expanding the number of contributors to debates on the TTIP.

\section{Using the TTIP to increase ideological cleavages between political factions in the $\mathrm{EP}$}

Buonanno (2017) states that politics is about perceptions and that constituency perceptions matter for agreements requiring EP legislative ratification. Thus, RLEs used the EP as an additional forum to change European society's and politicians' perceptions of the TTIP and to increase the ideological cleavage between political factions (Brack, 2018; Nielsen \& Franklin, 2017). Debates about the TTIP were useful for illustrating RLEs' ideological profiles and differentiating them from their main competitors. In May 2013, MEPs discussed the resolution on trade and investment agreement negotiations with the US (European Parliament, 2013). In July 2014, they deliberated on the EC statement on the TTIP (European Parliament, 2014), and in July 2015, they debated the resolution on negotiations surrounding the TTIP (European Parliament, 2015).

4) The campaign can be observed in tweets with the hashtags \#anti-TTIP and \#StopTTIP and Facebook accounts connected with anti-TTIP movements. 
The EP voted on the first resolution just before the TTIP's salience increased. The overwhelming majority of MEPs from different ideological areas supported the TTIP one year before the next election to the EP (461 for the resolution and 105 against, with 30 abstentions). The pro-TTIP camp included not only the European People's Party (EPP) and Group of the Alliance of Liberals and Democrats for Europe (ALDE) but also the Group of the Progressive Alliance of Socialists and Democrats (S\&D) on the left and the European Conservatives and Reformists Group and the Europe of Freedom and Democracy Group (EFD) on the right and radical right. Thus, the debate and voting on this resolution indicated no ideological cleavage between mainstream politicians on the left and the right. However, a cleavage did exist between RLEs and the rest of the MEPs. The GUE/NGL (and the Group of the Greens/European Free Alliance) tried to use the TTIP to differentiate themselves from their political opponents on the left and right. Additionally, this vote showed that RLE MEPs diverged from the S\&D and the EFD. For the social-democrat and radical-right parties, this issue was not controversial, as their occasional participation in debates about the resolution shows. In their remarks, they emphasized that their support for the TTIP depended on particular regulations, and they largely did not attack the TTIP. In contrast, RLE MEPs emphasized the threats that dominated public opinion in subsequent years. Their speeches noted the degradation of food standards (e.g., chlorinated chicken, meat with hormones, and GMOs), anxiety over ISDS, the reduced protection for labor rights, the erosion of consumer rights, and the secrecy of negotiations (European Parliament, 2013; Organ, 2017; Tereszkiewicz, 2020). These arguments were characteristic of far-left Euroskeptics because they were linked with the sources of their Euroskepticism, such as anti-capitalism, anti-globalism, and distrust of EC activity. However, in the initial debate, the ideological cleavage in the EP was relatively low because the TTIP was only important to RLE MEPs.

The next debate on the EC statement was conducted in the EP on July 15, 2014. A vote was not held after this debate, but the discussion included arguments used by RLEs in the EP in 2014, when the saliency of the TTIP was already established and societal contestation began to grow within a few EU member states. The rejection of the TTIP was mentioned as one of the RLEs' most important goals for the new EP term, citing the reduced protections for labor rights as the primary reason for their opposition. However, other issues, such as agriculture, environmental degradation, and the privatization of public services were clearly part of their arguments as well (European Parliament, 2014; Tereszkiewicz, 2020). This focus on labor rights among RLE MEPs can be interpreted as evidence that they tried to increase the ideological cleavage between MEPs on the left and the right. Their points for debate differentiated them not only from the mainstream EPP and ALDE party groupings but also from their RRE counterparts. Their strategy was also a useful tool in their rivalry with S\&D politicians, who focused on threats to labor rights protections in secret negotiations rather than in their speeches, which mainly approved of the TTIP. Additionally, an analysis of the RRE 
MEPs' arguments during this debate shows that they not only shifted to an anti-TTIP position but also began using arguments from RLE speeches in the previous EP debate, which were highlighted in anti-TTIP demonstrations and social media posts. Various arguments, such as anxiety about GMOs, concerns about meat with hormones, and the secrecy of the TTIP negotiations, were mentioned in statements by RRE MEPs. Thus, the ideological cleavage clearly grew on the meso and macro levels. Additionally, some indicators suggest that the RREs' shift to an anti-TTIP position was at least indirectly inspired by RLEs. The radical left's framing strategy was successful because their radical right opponents took on the negative narrative about the TTIP. However, they fortified it with new arguments, such as threats to traditional European food specialties (Tereszkiewicz, 2020).

The second resolution was adopted on July 8, 2015, two years after the first resolution and at a time when the polarization of European society was accelerating. As previously mentioned, the political and societal situations around the TTIP changed in 2014, and, thus, increased cleavages between Europhiles and Euroskeptics and between the right and left wings were observable in the EP (Eliasson \& Huet Garcia-Duran, 2018; Roederer-Rynning, 2017). The discussion of the second resolution shows that a majority of the EP still supported the TTIP. However, the vote exposed a shift in opinion, especially among Social Democrats and RREs, indicating an increased ideological cleavage in the EP at all levels of politicization. Additionally, a division in the EP between pro-TTIP mainstream parties (except for some S\&D MEPs) and anti-TTIP Euroskeptics is also evident. Unlike their main competitors on the left and the radical right, RLE MEPs remained cohesive in their negative attitudes toward the TTIP. Their arguments from previous debates held firm, with the most popular touchpoints being the reduction of labor rights protections, anxiety over ISDS, and the privatization of public services (European Parliament, 2015). Examining the debate shows that S\&D and RRE MEPs used arguments that were taken from RLEs. Some S\&D MEPs and almost all radical-right MEPs rejected the treaty, stressing such concerns as anxiety over ISDS, rising unemployment rates in the EU, and a decrease in food security. The latter argument is notable because RLE MEPs did not highlight food safety concerns in this debate even though the issue was very popular among civil society organizations and movements that conducted anti-TTIP campaigns at that time. This finding may indicate that the main competitors of RLEs were more aware of popular concerns about the TTIP within European society in 2015 relative to radical-left MEPs. However, the arguments used by RLE MEPs during this debate were more in line with their ideological profile because they expressed their opposition to trade liberalization, marketization, and privatization along with their pessimism about the EU's current direction. RLE MEPs focused more on coherence with their ideological profile. At the same time, RRE deputies put forth arguments about ISDS and the degradation of food standards.

This analysis identifies some indicators of a correlation between RLE activity and expanded 
ideological cleavages between and within political factions in the EP. At first, the TTIP was uncontroversial, and RLE MEPs formed almost the only opposition to the treaty. However, as the polarization of the issue within European society increased, a shift in the EP also occurred. Some S\&D MEPs and almost all RRE MEPs shifted from positive and neutral positions on the TTIP to negative positions. The increasingly negative public opinion toward this treaty was probably the main motivation for this decision rather than the positions of RLEs in the EP. However, the use of RLE arguments by S\&D, European Freedom and Direct Democracy, and Europe of Nations and Freedom deputies demonstrate direct and indirect correlations between RLE activity and the politicization of the TTIP in the EP.

\section{Conclusion}

Several researchers have recognized the influence of anti-TTIP activists on European society in several EU member states (Bluth, 2016; Eliasson \& Huet Garcia-Duran, 2018; Fabry, 2015; Gheyle, 2020). This study lends credence to that process by suggesting that RLE activity and the politicization of the TTIP are positively correlated. This analysis positively answers four questions investigating RLEs' politicization of the TTIP on four levels by showing that RLEs raised the TTIP's salience, increased the polarization of public opinion and politicians' orientations, involved social actors and NGOs in the debate on the TTIP, and used the treaty to increase the ideological cleavages between political factions in the EP. Thus, my hypothesis is verified.

First, it is notable that at the beginning of TTIP negotiations, this topic was not high on political agendas and was not a major concern of European society. Thus, the salience of this issue was low. The early lack of interest was because the TTIP, as an economic and technical issue, did not draw public attention. The fact that public opinion regarding the TTIP became increasingly radicalized between 2014 and 2015 suggests a positive correlation between RLE activity and the TTIP's politicization. This study shows that radical-left parties, civil society organizations, and social movements profoundly affected public opinion on the TTIP initially by increasing its salience during the EP elections in 2014 in France and Germany. Second, they involved social actors and NGOs in anti-TTIP campaigns and channeled European anxieties into the STOP TTIP European Citizens' Initiative (the expansion of actors). Third, the agreement was used by RLEs to increase polarization within European society and expand the ideological cleavages within the EP. Finally, we can assume that the anti-TTIP campaign would have had different drivers if RREs had promoted it.

The TTIP was the target issue for these activities because RLEs oppose the EU, mainly because of the neoliberal direction of the European integration process. The TTIP, a new partnership with the US, was seen by RLEs as the quintessence of global capitalism and as 
evidence that international corporations were steering the EU in a direction that was decidedly against popular interest. This anti-EU narrative around the TTIP steadily gained attention in parts of European society because indications suggest that RLEs initially used arguments that had become popular in the public discourse, such as the threat to food security and anxiety over ISDS. Furthermore, many of these anti-EU radical-left arguments were taken up by MEPs in EP debates, suggesting that RLEs were the source of the TTIP's politicization not only within European society but also among members of the EU legislature. However, they had only an indirect influence in the EU legislature because S\&D and RRE MEPs were inspired by anti-TTIP social movements in their home countries.

This study provides some indications as to how RLEs politicized the TTIP, which helps in understanding how RLEs may politicize other DCFTAs and EU trade policy as a whole. However, knowledge as to why RLEs politicize these issues remains limited, and this area requires further investigation. Another potentially interesting direction of research is the question of whether RLEs politicize the EU as a whole differently from their far-right counterparts. Some indicators suggest that the politicization of the EU may appear similar in both cases, but the contents of the process may differ. I show that the TTIP's politicization can be considered full because it RLEs carried it out on all levels in accordance with the pattern of politicization. However, the profile of RLEs determined the arguments that were used in the politicization process. This issue requires deeper investigation in the future.

\section{References}

Akcja Demokracja. (2015). Nie dla sądów arbitrażowych w TTIP. Retrieved October 1, 2020, from https:// dzialaj.akcjademokracja.pl/campaigns/sadyarbitrazowe?utm_medium=twitter

ATTAC. (n.d.). About ATTAC. Retrieved September 23, 2020, from https://www.attac.org/en/overview Bauer, M. (2015a). Campaign-triggered mass collaboration in the EU's online consultations: the ISDS-inTTIP case. European View, 14, 121-129. doi: 10.1007/s12290-015-0346-6

Bauer, M. (2015b). The spiral of silence - How anti-TTIP groups dominate German online media and set the tone for TTIP opinion. European Centre for International Political Economy. Retrieved from https://ecipe.org/blog/anti-ttip-german-online-media/

Bauer, M. (2016). Manufacturing discontent: The rise to power of Anti-TTIP groups. ECIPE Occasional Paper 2. European Centre for International Political Economy. Retrieved from https://ecipe.org/wp-cont ent/uploads/2016/11/Manufacturing-Discontent.pdf

Behrens, J. (2015). Erfolg: 2 millionen unterschriften gegen TTIP \& CETA [Blog post]. Retrieved from https://blog.campact.de/2015/06/erfolg-2-millionen-unterschriften-gegen-ttip-ceta/?pk_vid=a3215e0cf1 eed6e $015910925111129 \mathrm{bd}$

Bernasconi-Osterwalder, N., \& Tamara Hoffmann, R. (2012). The German nuclear phase-out put to the 
test in international investment arbitration? Background to the new dispute Vattenfall v. Germany (II). Retrieved from https://www.iisd.org/pdf/2012/german_nuclear_phase_out.pdf

Bluth, C. (2016). Attitudes to global trade and TTIPP in Germany and the United States. Gütersloh: Bertelsmann Stifung

Brack, N. (2018). Opposing Europe in the European Parliament: Rebels and radicals in the hamber. London: Palgrave Macmillan.

Braun, D., Popa, S. A., \& Schmitt, H. (2019). Responding to the crisis: Eurosceptic parties of the left and right and their changing position towards the European Union. European Journal of Political Research, 58(3), 797-819. doi: 10.1111/1475-6765.12321

Buonanno, L. A. (2017). The new trade deals and the mobilisation of civil society organizations: Comparing EU and US responses. Journal of European Integration, 39(7), 795-809.

Buonanno, L. A., Cuglesan, N., \& Henderson, K. (Eds.). (2015). The new and changing transatlanticism: Politics and policy perspectives. Abingdon: Routledge.

Burchard, H. (2016). The man who killed TTIP. Politico. Retrieved from https://www.politico.eu/article/theman-who-killed-ttip-thilo-bode-foodwatch-germany-free-trade/

Campact. (n.d.). TTIP, CETA und Co.: Die Meilensteine. Retrieved April 1, 2021, from https://www.campa ct.de/handelspolitik/

Campact. (2015). Danke für diesen Gänsehautmoment [Blog post]. Retrieved from https://blog.campact.de/ 2015/10/danke-fuer-diesen-gaensehautmoment/

Campact. (2016). 320.000 protestieren gegen CETA und TTIP in 7 Städten [Video file]. Retrieved from https:/www.youtube.com/watch?v=fbialiR15gA\&t $=9 \mathrm{~s}$

Campagna STOP TTIP Italia. (2015a). Cos'è il TTIP. Retrieved April 1, 2021, from https://stop-ttip-italia.n et/cose-il-ttip/

Campagna STOP TTIP Italia. (2015b). ONU, parla l'esperto: l'ISDS è contro i diritti umani, stop ai negoziati TTIP. Retrieved April 1, 2021, from https:/stop-ttip-italia.net/2015/10/27/onu-esperto-isds-co ntro-diritti-umani-stop-ttip-333/\#more-1873

Campagna STOP TTIP Italia. (2016a). \#StopTTIP \#7M. Una splendida giornata. Retrieved April 2, 2021, from https://stop-ttip-italia.net/2016/05/08/stopttip-7m-una-splendida-giornata/

Campagna STOP TTIP Italia. (2016b). A Roma sindacati, imprese e associazioni incontrano il Ministro Calenda e la Presidente Boldrini. Retrieved April 2, 2021, from https://stop-ttip-italia.net/2016/07/05/ro ma-sindacati-imprese-associazioni-calenda-boldrini-333/

Campagna STOP TTIP Italia. (2016c). TTIP e posti di lavoro. Quanto ci perde l'Italia. Retrieved April 2, 2021, from https://stop-ttip-italia.net/2016/05/23/ttip-e-posti-di-lavoro-quanto-ci-perde-litalia/

Chan, A. T., \& Crawford, B. K. (2017). The puzzle of public opposition to TTIP in Germany. Business and Politics, 19(4), 683-708.

Charalambous, G. (2011). All the shades of red: Examining the radical left's Euroscepticism. Contemporary Politics, 17(3), 299-320.

Charalambous, G., Conti, N., \& Pedrazzani, A. (2018). The political contestation of European integration in Southern Europe: Friction among and within parties. Party Politics, 24(1), 39-51. doi: 10.1177/13540 68817740756 
Chiocchetti, P. (2014). The radical left at the 2014 European Parliament election. In C. Hildebrandt (Ed.), Situation on the Left in Europe after the EU Elections: New Challenges (pp. 7-14). Berlin: Rosa Luxemburg Stiftung.

Christiansen, T. (1997). Tensions of European governance: Politicized bureaucracy and multiple accountability in the European Commission. Journal of European Public Policy, 4(1), 73-90.

Comitato STOP TTIP Torino. (2016). Assemblea (macroregionale dei comitati STOP TTIP nord-ovest) per organizzare UNA GRANDE MANIFESTAZIONE NAZIONALE in Aprile a ROMA [Blog post]. Retrieved April 3, 2021, from http://stopttiptorino.blogspot.com/2016/02/27-febbraio-2016-torino-asse mblea.html

Conti, N., \& Memoli, V. (2012). The multi-faceted nature of party-based Euroscepticism. Acta Politica, 47(2), 91-112.

Costa, O. (2019). The politicization of EU external relations. Journal of European Public Policy, 26(5), 790-802.

Cyrus, T. L. (2015). Culture and trade in the European Union. Journal of Economic Integration, 30(2), 206-239. doi: 10.11130/jei.2015.30.2.206

De Bièvre, D. (2018). The paradox of weakness in European trade policy: Contestation and resilience in CETA and TTIP negotiations. The International Spectator, 53(3), 70-85.

De Ville, F., \& Siles-Brügge, G. (2017). Why TTIP is a game-changer and its critics have a point. Journal of European Public Policy, 24(10), 1491-1505.

De Vries, C. E. (2018). Euroscepticism and the future of European integration. Oxford: Oxford Scholarship Online.

De Vries, C. E., \& Edwards, E. E. (2009). Taking Europe to its extremes: Extremist parties and public Euroscepticism. Party Politics, 15(1), 5-28.

De Wilde, P. (2011). No polity for old politics? A framework for analyzing the politicization of European integration. Journal of European Integration, 33(5), 559-575.

De Wilde, P., Leupold, A. \& Schmidtke, H. (2016). Introduction: the differentiated politicisation of European governance. West European Politics, 39(1), 3-22. doi: 10.1080/01402382.2015.1081505

Die Linke. (2014). Große Anfrage. Soziale, ökologische, ökonomische und politische Effekte des EU-USA Freihandelsabkommens. Deutscher Bundestag, 18(432). Retrieved from http://dip21.bundestag.de/dip2 1/btd/18/004/1800432.pdf

Dunphy, R. (2004). Contesting capitalism? Left parties and European integration. Manchester: Manchester University Press.

Eliasson, L. J., \& Huet Garcia-Duran, P. (2018). TTIP negotiations: Interest groups, anti-TTIP civil society campaigns and public opinion. Journal of Transatlantic Studies, 16(2), 101-116.

European Commission. (2009). Standard Eurobarometer 72, Public Opinion in the European Union. Retrieved from https://ec.europa.eu/commfrontoffice/publicopinion/archives/eb/eb72/eb72_vol1_en.pdf

European Parliament. (2013). EU trade and investment agreement negotiations with the US (debate). Retrieved from http://www.europarl.europa.eu/sides/getDoc.do?pubRef=-//EP//TEXT+CRE+20130522 + ITEM-017+DOC+XML+V0//EN

European Parliament. (2014). Commission statement: Transatlantic Trade and Investment Partnership (TTIP). 
Retrieved from http://www.europarl.europa.eu/sides/getDoc.do?pubRef=-//EP//TEXT+CRE+20140715 + ITEM-009+DOC+XML+V0//EN

European Parliament. (2015). Negotiations for the Transatlantic Trade and Investment Partnership (TTIP) (debate). Retrieved from http://www.europarl.europa.eu/sides/getDoc.do?pubRef=-//EP//TEXT+CRE+ 20150707+ITEM-004+DOC+XML+V0//EN

Fabry, E. (2015). France: A hotbed of opposition to the TTIP? Policy Paper, 136. Notre Europe Jacques Delors Institut. Retrieved from http:/www.institutdelors.eu/wp-content/uploads/2018/01/francettip-fabr y-jdidgap-june15.pdf?pdf=ok

Foodwatch. (2015a). Auch INSM korrigiert Falschinformationen über TTIP. Retrieved October 10, 2020, from https://www.foodwatch.org/de/aktuelle-nachrichten/2015/auch-insm-korrigiert-falschinformation en-ueber-ttip/

Foodwatch. (2015b). Falschinformation: Wir stellen richtig. Retrieved April 3, 2021, from https://www.food watch.org/de/newsletter/2015/falschinformation-wir-stellen-richtig/

Garcia-Duran, P., \& Eliasson, L. J. (2017). The public debate over transatlantic trade and investment partnership and its underlying assumptions. Journal of World Trade, 51(1), 23-42.

Gheyle, N. (2016). Trade policy with the lights on. Linking trade and politicization. Paper prepared for the conference: EU Trade Policy at the Crossroads: between Economic Liberalism and Democratic Challenges, 4-6 February 2016, Vienna, Austria. Retrieved from https://www.oefse.at/fileadmin/content /Downloads/tradeconference/Gheyle_Trade_Policy_with_the_Lights_on_Linking_Trade_and_Politiciz ation.pdf

Gheyle, N. (2020). Huddle up! Exploring domestic coalition formation dynamics in the differentiated politicization of TTIP. Politics and Governance, 8(1), 301-311. doi: 10.17645/pag.v8i1.2588

Grande, E., \& Hutter, S. (2016). Beyond authority transfer: Explaining the politicisation of Europe. West European Politics, 39(1), 23-43.

Green-Pedersen, C. (2012). A giant fast asleep? Party incentives and the politicisation of European integration. Political Studies, 60(1), 115-130.

Greenpeace. (2016a). Greenpeace activists block secret TTIP talks. Retrieved April 5, 2021, from https://w ww.greenpeace.org/eu-unit/issues/democracy-europe/652/greenpeace-activists-block-secret-ttip-talks/

Greenpeace. (2016b). Leaked TTIP documents released. Retrieved October 10, 2020, from http://www.gree npeace.org/eu-unit/en/News/2016/Leaked-TTIP-documents-released/

Griller, S., Obwexer, W., \& Vranes, E. (2017). Mega-regional trade agreements: New orientations for EU external relations? In S. Griller, W. Obwexer, \& E. Vranes (Eds.), Mega-regional Trade Agreements: CETA, TTIP, and TiSA: New Orientations for EU External Economic relations (pp. 3-16). Oxford: Oxford University Press.

Guinaudeau, I., \& Persico, S. (2013). EU politicization through the lens of salience: How the EU enters the French, British and German electoral agenda (1986-2009). French Politics, 11(2), 143-168.

Halikiopoulou, D. (2014). Far left-wing Euroscepticism in the 2014 EP Elections: A cross--European Comparison. In K. Ifantis (Ed.), Is Europe Afraid of Europe? An Assessment of the Result of the 2014 European Elections (pp. 112-126). Athens: Wilfried Martens Centre for European Studies/Karamanlis Foundation. 
Halikiopoulou, D. (2018). A right-wing populist momentum? A review of 2017 elections across Europe. JCMS: Journal of Common Market Studies, 56(1), 63-73.

Halikiopoulou, D., Nanou, K., \& Vasilopoulou, S. (2012). The paradox of nationalism: The common denominator of radical right and radical left Euroscepticism. European Journal of Political Research, 51(4), 504-539.

Helbling, M., Höglinger, D., \& Wüest, B. (2010). How political parties frame European integration? European Journal of Political Research, 49(4), 495-521.

Hix, S., \& Lord, C. (1997). Political parties in the European Union. Basingstoke: Palgrave.

Hoeglinger, D. (2015). Politicizing European integration: Struggling with the awakening giant. Basingstoke: Palgrave Macmillan.

Holmes, M., \& Lightfoot, S. (2016). To EU or not to EU? The transnational radical left and the crisis. In L. March \& K. Daniel (Eds.), Europe's Radical Left: From Marginality to Mainstream? (pp. 333-351). London: Rowman \& Littlefield International.

Hooghe, L., \& Marks, G. (2009). A postfunctionalist theory of European integration: From permissive consensus to constraining dissensus. British Journal of Political Science, 39(1), 1-23.

Hooghe, L., Marks, G., \& Wilson, C. J. (2002). Does left/right structure party positions on European integration? Comparative Political Studies, 35(8), 965-989.

Hough, D., \& Handl, V. (2004). The post-communist left and the European Union: The Czech Communist Party of Bohemia and Moravia (KSČM) and the German Party of Democratic Socialism (PDS). Communist and Post-Communist Studies, 37(3), 319-339.

Instytut Spraw Obywatelskich. (n.d.). O nas. Retrieved October 9, 2020, from https://instytutsprawobywatel skich.pl/o-nas/

Keith, D. (2017). Stop TTIP': towards a transnational Eurosceptic opposing the Transatlantic Trade and Investment Partnership? In J. FitzGibbon, B. Leruth, \& N. Startin (Eds.), Euroscepticism as a Transnational and Pan-European Phenomenon. The Emergence of a New Sphere of Opposition (pp. 97-112). Abingdon: Routledge.

Keith, D. (2018). Opposing Europe, opposing austerity: Radical left parties and the Eurosceptic debate. In B. Leruth, N. Startin, \& S. Usherwood (Eds.), The Routledge Handbook of Euroscepticism (pp. 36-47). Abingdon: Routledge.

Kopecký, P., \& Mudde, C. (2002). The two sides of Euroscepticism: Party positions on European integration in East Central Europe. European Union Politics, 3(3), 297-326.

Leconte, C. (2015). From pathology to mainstream phenomenon: Reviewing the Euroscepticism debate in research and theory. International Political Science Review, 36(3), 250-263.

Leruth, B., Startin, N., \& Usherwood, S. (2018). Defining Euroscepticism. From a broad concept to a field of study. In B. Leruth, N. Startin, \& S. Usherwood (Eds.), The Routledge Handbook of Euroscepticism (pp. 1-10). Abingdon: Routledge.

Majone, G. (2002). The European Commission: The limits of centralization and the perils of parliamentarization. Governance: An International Journal of Policy, Administration, and Institutions, 15(3), 375-392.

March, L. (2008). Contemporary far left parties in Europe: From Marxism to the mainstream? Berlin: 
Friedrich Ebert Stiftung.

March, L., \& Rommerskirchen, C. (2015). Out of left field? Explaining the variable electoral success of European radical left parties. Party Politics, 21(1), 40-53.

Mayer, H. (2016). Between 'NATO for trade' and 'Pride in Angs': The German TTIP debate and its spill-over into wider transatlantic concerns. In J.-F. Morin, T. Novotna, F. Ponjaert, \& M. Telo (Eds.), The Politics of Transatlantic Trade Negotiations: TTIP in a Globalized World (pp. 45-58). Abingdon: Routledge.

Meijers, M. J. (2015). Contagious Euroscepticism: The impact of Eurosceptic support on mainstream party positions on European integration. Party Politics, 23(4), 413-423.

Meijers, M. J. (2017). Radical right and radical left Euroscepticism: A dynamic phenomenon. Policy Paper, 191, Jacques Delors Institut. Retrieved from http://www.delorsinstitut.de/2015/wp-content/uploa ds/2017/04/20170407_Euroscepticism-Meijers.pdf

Meunier, S., \& Morin, J.-F. (2017). The European Union and the space-time continuum of investment agreements. Journal of European Integration, 39(7), 891-907.

Mélenchon, J.-L. (2014). Huit ans de lutte contre le Grand Marché Transatlantique (GMT-TTIP-TAFTA) [Blog post]. Retrieved April 7, 2021, from https://melenchon.fr/2014/04/22/six-ans-de-lutte-contre-le-g rand-marche-transatlantique-gmt-ttip-tafta/

Mélenchon, J. L. (2015a). GMT: Les négociations se poursuivent malgré l'opposition citoyenne [Blog post]. Retrieved April 7, 2021, from http://europe.jean-luc-melenchon.fr/2015/02/26/gmt-les-negociatio ns-se-poursuivent-malgre-lopposition-citoyenne/

Mélenchon, J. L. (2015b). GMT: L'Europe autoritaire s'affiche [Blog post]. Retrieved April 7, 2021, from https://melenchon.fr/2015/10/03/gmt-leurope-autoritaire-saffiche/

Mélenchon, J. L. (2015c). Grand Marché Transatlantique: Les tribunaux d'arbitrage avancent masques [Blog post]. Retrieved April 8, 2021, from http://europe.jean-luc-melenchon.fr/2015/05/19/grand-marc he-transatlantique-les-tribunaux-darbitrage-avancent-masques/

Mélenchon, J. L. (2016). TAFTA: La France tient la chandelle! [Blog post]. Retrieved April 9, 2021, from https://melenchon.fr/2016/04/26/tafta-france-tient-bougie/

Morin, J. F., Novotná, T., Ponjaert, F., \& Telò, M. (2015). The politics of transatlantic trade negotiations: TTIP in a globalized world. Abingdon: Routledge.

Nielsen, J. H., \& Franklin, M. N. (2017). The 2014 European Parliament Elections: Still Second Order? In J. H. Hassing \& M. Franklin (Eds.), The Eurosceptic 2014 European Parliament Elections (pp. 1-16). London: Palgrave Macmillan. doi: 10.1057/978-1-137-58696-4_1

Organ, J. (2017). EU citizen participation, openness and the European Citizens Initiative: The TTIP legacy. Common Market Law Review, 54(6), 1713-1747.

Petersmann, E.-U. (2017). CETA, TTIP, and TiSA: New trends in international economic law. In S. Griller, W. Obwexer, \& E. Vranes (Eds.), Mega-regional Trade Agreements: CETA, TTIP, and TiSA: New Orientations for EU External Economic Relations (pp. 17-43). Oxford: Oxford University Press.

Pirro, A., \& Taggart, P. (2018). The populist politics of Euroscepticism in times of crisis: A framework for analysis. Politics, 38(3), 253-262. doi: 10.1177/0263395718770579

Puntscher Rieckmann, S. (2017). The struggle for and against globalisation: International trade agreements 
and the democratic question. In S. Griller, W. Obwexer, \& E. Vranes (Eds.), Mega-Regional Trade Agreements: CETA, TTIP, and TiSA. New Orientations for EU External Economic Relations (pp. 286-294). Oxford: Oxford University Press.

Razem. (2016). Razem przeciwko TTIP [Facebook update]. Retrieved April 10, 2021, from https://www.fac ebook.com/partiarazem/photos/a.430709850430410/599204360247624/

Rixen, T., \& Zangl, B. (2013). The politicization of international economic institutions in US public debates. The Review of International Organizations, 8(3), 363-387.

Roederer-Rynning, C. (2017). Parliamentary assertion and deep integration: The European parliament in the CETA and TTIP negotiations. Cambridge Review of International Affairs, 30(5/6), 507-526.

Rone, J. (2018). Contested international agreements, contested national politics: How the radical left and the radical right opposed TTIP in four European countries. London Review of International Law, $6(2), 233-253$.

Rooduijn, M., Burgoon, B., Van Elsas, E. J., \& Van de Werfhorst, H. G. (2017). Radical distinction: Support for radical left and radical right parties in Europe. European Union Politics, 18(4), 536-559.

Scharpf, F. (1996). Negative and positive integration in the political economy of European welfare states. In F. Scharpf (Ed.), Community and Autonomy: Institutions, Policies and Legitimacy in Multilevel Europe (pp. 91-126). Cologne: Max Planck Institute for the Study of Societes.

Schmidtke, H. (2013). The entry of the laity into the altar of international relations: Why international institutions become publicly contested. In 7th ECPR Annual Conference. Bordeaux. Retrieved from https://ecpr.eu/Filestore/PaperProposal/8487e12f-7b6a-43dc-bace-c72ddf28f150.pdf

Schmitter, P. C. (1969). Three neo-functional hypotheses about international integration. International Organization, 23(1), 161-166.

Scholz, H. (2015a). Ein System, früher ISDS genannt [Blog post]. Retrieved from https://www.helmutschol z.eu/de/article/592.ein-system-früher-isds-genannt.html?sstr=ttip

Scholz, H. (2015b). Kapitulation der Demokratie [Blog post]. Retrieved from https://www.helmutscholz.eu/ de/article/528.kapitulation-der-demokratie.html

Scholz, H. (2015c). TTIP, trade and regulatory co-operation: Benefits and costs. Retrieved from https://www. guengl.eu/news/article/events/ttip-trade-and-regulatory-co-operation-benefits-and-costs.-5-march-2015

Ségol. B. (2015). 2015 biennial delegate conference (ICTU). Retrieved April 15, 2021, from https://www.et uc.org/en/speech/2015-biennial-delegate-conference-ictu-speech-bernadette-segol

Siles-Brügge, G. (2017). Transatlantic investor protection as a threat to democracy: The potency and limits of an emotive frame. Cambridge Review of International Affairs, 30(5/6), 464-488.

Smyrnaios, N. (n.d.). The movement against TTIP-TAFTA on Twitter. Pressbooks, 24. Retrieved October 10, 2020, from https://pauljreilly.pressbooks.com/chapter/the-movement-against-ttip-tafta-on-twitter/

Smyrnaios, N. (2014). The movement against TTIP-TAFTA on Twitter. Retrieved April 9, 2021, from http://ephemeron.eu/1335

Standard Eurobarometer 82. (2014). Public opinion in the European Union. Report. Retrieved from https://e c.europa.eu/commfrontoffice/publicopinion/archives/eb/eb82/eb82_publ_en.pdf

Standard Eurobarometer 84. (2015). Public opinion in the European Union. Report. Retrieved from https://data.europa.eu/euodp/pl/data/dataset/S2098_84_3_STD84_ENG 
Steiner, N. D. (2016). Public support for TTIP in EU countries: What determines trade policy preferences in a salient case? The ECPR Graduate Student Conference. University of Tartu. Retrieved from https://e cpr.eu/Filestore/PaperProposal/76df7ee3-cef3-4860-90dc-ff414071ccca.pdf

Stop TAFTA. (n.d.). Régions, départements, communes hors TAFTA, non au traité transatlantique. Retrieved October 11, 2020, from https://stoptafta.wordpress.com/mobilisations/

STOP TTIP. (2015). About STOP TTIP. Retrieved September 25, 2020, from https://stop-ttip.org/about-sto p-ttip/

STOP-TTIP-Milano. (n.d.). La produzione del Cibo: Alternative sostenibili [Blog post]. Retrieved April 2, 2021 from http://stop-ttip-milano.net/tag/cibo/

Szczerbiak, A., \& Taggart, P. (2018). Contemporary research on Euroscepticism. The state of the art. In B. Leruth, N. Startin, \& S. Usherwood (Eds.), The Routledge Handbook of Euroscepticism (pp. 11-21). Abingdon: Routledge.

Taggart, P., \& Szczerbiak, A. (2004). Contemporary Euroscepticism in the party systems of the European Union candidate states of Central and Eastern Europe. European Journal of Political Research, 43(1), $1-27$.

Tereszkiewicz, F. (2020). Eurosceptic attitudes towards the transatlantic trade and investment partnership: Who are the trendsetters and followers? Online Journal Modelling The New Europe, 32, 4-20. doi: 10.24193/OJMNE.2020.32.01

Tilly, C., \& Tarrow, S. (2007). Contentious politics. Boulder: Paradigm Publishers.

TNS Emnid. (2015). Foodwatch. Retrieved October 9, 2020, from http://www.foodwatch.org/fileadmin/The men/TTIP_Freihandel/Dokumente/2015-10_ttip_umfrage.pdf

Traité transatlantique: nouvelles négociations secrètes à 5 jours des élections. (2014). L'Humanite. Retrieved from https://www.humanite.fr/traite-transatlantique-nouvelles-negociations-5-jours-des-elections-532267

Troisi, R. (2016). TTIPLEAKS [Facebook update]. Retrieved April 11, 2021, from https://www.facebook.c om/riccardotroisi/posts/10208851170670299

TTIP Free Zones Europe. (n.d.). Homepage. Retrieved April 10, 2021, from https://www.ttip-free-zones.eu Über Campact. (n.d.). Campact. Retrieved October 6, 2020, from https://www.campact.de/campact/

Van Elsas, E. J., Hakhverdian, A., \& van der Brug, W. (2016). United against a common foe? The nature and origins of Euroscepticism among left-wing and right-wing citizens. West European Politics, 39(6), 1181-1204.

Vasilopoulou, S. (2011). European integration and the radical right: Three patterns of opposition. Government and Opposition, 46(2), 223-244.

Volkens, A. (2004). Policy positions of left parties in the 1999-2004 European Parliament: Programmatic similarities and differences. Die Rosa-Luxemburg-Stiftung. Retrieved from https://www.rosalux.de/file admin/rls_uploads/pdfs/Themen/leftparties/pdfs/Volkens_LeftPartyEurope_e.pdf

Williams, C., \& Ishiyama, J. (2018). Responding to the left: the effect of far-left parties on mainstream party Euroskepticism. Journal of Elections, Public Opinion and Parties, 28(4), 443-466.

Winslett, G. (2016). How regulations become the crux of trade politics. Journal of World Trade, 50(1), 47-70.

Xavier-Bender, G. (2015). France's unexpected role on the way to a reasonable and balanced TTIP. Europe 
Policy Paper, 2. The German Marshall Fund of the United States. Retrieved from http://www.gmfus.org /file/6126/download

YouGov Deutschland. (2015). Mehr TTIP-Gegner in Deutschland als anderswo. Retrieved April 9, 2021, from https://yougov.de/news/2015/03/31/viele-deutsche-sind-gegen-ttip/

Young, A. R. (2016). Not your parents' trade politics: The Transatlantic Trade and Investment Partnership negotiations. Review of International Political Economy, 23(3), 345-378.

Young, A. R. (2017). The new politics of trade. Lesson from TTIP. Newcastle: Agenda Publishing.

Zürn, M. (2016). Opening up Europe: Next steps in politicisation research. West European Politics, 39(1), 164-182. doi: 10.1080/01402382.2015.1081513 